\title{
HUBUNGAN SIKLUS PUTARAN DAN BEBAN TERHADAP KEKUATAN BAHAN PADA UJI FATIK BENDING
}

\author{
Tri Cahyo Wahyudi, Eko Nugroho \\ Program Studi Teknik Mesin Fakultas Teknik Universitas Muhammadiyan Metro \\ Jl. KH. Dewantara No. 116 Metro Telp. (0725) 45932-42445 Kode Pos 34111 \\ tri_cahyo@yahoo.com
}

\begin{abstract}
ABSTRAK
Uji fatik bending merupakan salah satu alat uji untuk mengetahui tingkat kelelahan suatu bahan yang akan digunakan sebagai konstruksi atau komponen yang akan menerima pembebanan . Fungsi uji fatik bending adalah menguji kekuatan patah berdasarkan beban bending yang berbeda- beda mulai dari beban rendah sampai beban yang besar. Mekanisme patah lelah terdiri atas 3 tahap yakni: Tahap awal terjadinya retakan, Tahap penjalaran retakan dan Tahap akhir kerusakan / patah. Tujuan pengujian fatik bending Mengetahui hubungan siklus putaran dan beban terhadap kekuatan bahan uji, Menentukan nilai hubungan dan tegangan yang terjadi siklus terhadap putaran, Menentukan Jenis bahan yang mana memiliki keuletan dan kegetasan terhadap jenis patahan. Cara kerja uji fatik bending yaitu benda uji di jepit pada ragum penjepit yang dihubungkan dengan poros yang digerakan oleh motor listrik dan pada poros penjepit di beri pemberat, kemudian benda uji tersebut di putar. pada waktu tertentu benda uji tersebut mengalami kelelahan fatik sehingga akan putus (patah) dengan menggunakan variasi beban 9,81 N, $14,72 \mathrm{~N}, 19,62 \mathrm{~N}, 24,53 \mathrm{~N}$ dan 29,43 N. Dan tiap-tiap benda uji memiliki ukuran diameter $4 \mathrm{~mm}, 5 \mathrm{~mm}$ dan $6 \mathrm{~mm}$ bahan yang di gunakan yakni bahan St 37 dan St 40 dengan putaran motor $1486 \mathrm{rpm}$. Hubungan siklus putaran dan beban terhadap kekuatan bahan uji ini menunjukan semakin kecil beban maka jumlah siklus putaran akan semakin besar dengan jumlah siklus tertinggi yakni 15085,9. Putaran sangat erat hubungan nya dengan tegangan benda uji, Karena semakin besar tegangan maka akan semakin kecil jumlah siklus putaran,dan sebaliknya. Pada nilai hubungan tegangan dengan siklus putaran terlihat tegangan terkecil $0,34 \mathrm{~N} / \mathrm{mm}^{2}$ untuk jumlah siklus tertinggi 15085,9. Dalam proses pengujian terlihat hasil bahwa nilai kekerasan yang tinggi yaitu 40,98 menunjukan patah getas pada bahan nya dan nilai kekerasan yang rendah yaitu 39,90 yang memiliki bahan patah ulet.
\end{abstract}

Kata kunci : Uji fatik bending, Kelelahan, Kekersan.

\section{PENDAHULUAN}

Kegagalan lelah adalah hal yang sangat membahayakan, karena terjadi tanpa petunjuk awal. Kelelahan mengakibatkan patah yang terlihat rapuh, tanpa deformasi pada patahan tersebut. Pengujian bahan dilakuakan dengan tujuan diantaranya untuk mengetahui karakteristik bahan dan kemampuan terhdap pembebanan tertentu, maka dapat di lakukan pemilihan beban dan putaran yang sesuai untuk pemakainan.

Patah lelah disebabkan oleh pembebanan bolak balik secara berulang dalam waktu atau siklus tertentu. Kelelahan muncul ketika suatu benda mengalami kegagalan (kerusakan) setelah menerima suatu beban terus-menerus secara berulang- ulang. Suatu benda yang mengalami kegagalan kelelahan biasanya dimulai dengan adanya pecahan bahan pada permukaan objek itu. Seiring berjalannya waktu, pecahan itu membentuk retakan yang semakin besar, sampai pada suatu saat retakan itu telah cukup besar untuk menyebabkan suatu kerusakan pada objek tersebut (patah).

Pengujian lengkung (bending) merupakan sal ah satu pengujian sifat mekanik bahan yang dilakukan terhadap speimen dari bahan baik bahan yang akan digunakan sebagai konstruksi atau komponen yang akan menerima pembebanan lengkung maupun proses pelengkungan dalam pembentukan. Pelengkungan (bending) merupakan proses pembebanan terhadap suatu bahan pada satu bagian yaitu ditengah-tengah dari bahan yang kemudian ditahan pada kedua sisi benda yaitu di tumpu. 
Hubunngan antara pengujian fatik dengan bending sangat berkaitan menigigat sebagian besar kerusakan yang terjadi pada kontruksi permesinan disebabkan oleh kegagalan lelah. Kelelahan adalah salah ssatu jenis kegagalan (patah) pada komponen akibat pembebanan yang berulang-ulang atau berubahubah. Diperkirakan 50\%, 90\% kelelahan yang terjadi disebabkan oleh faktor mekanis.

Putaran yang mempengaruhi fatik bending padapengujian ini yang di ukur dengan tachometer, dan putaran tersebut digunakan untuk mendapatkan pengaruh pembebanan pada spesimen. Kemudian banyak putaran seringkali tinggi maka kelelahan pada satuan beban tertentu yang dialami bahan.

Pembebanan maksimum yang digunakan pada pengujian fatik yang menerima beban lentur dan puntir. Karena beban pada pengujian ini berpengruh pada hasil benda yg uji. Semakin besar beban yang di alami bahan maka akan semakin cepat dan pasti bahan akan mengalami putus atau patah, dan sebaliknya.

Tujuan dari uji fatik ini adalah untuk mengetahui karakteristik material yang berhubungan dengan beban dinamis yaitu kekuatan fatik. Kegunaan dari uji fatik adalah hasil dari pengujian nantinya akan digunakan dalam perancangan produk, yaitu sebagai faktor pertimbangan dalam memilih materialyang tepat untuk suatu rancangan.

\section{LANDSAN TEORI}

\section{Uji Fatik Bending}

Uji fatik bending merupakan salah satu alat uji untuk mengetahui tingkat kelelahan suatu bahan yang akan digunakan sebagai konstruksi atau komponen yang akan menerima pembebanan. Fungsi uji fatik bending adalah menguji kekuatan patah berdasarkan beban bending yang berbeda- beda mulai dari beban rendah sampai beban yang besar.

Kelelahan fatikmuncul ketika suatu benda mengalami kegagalan (kerusakan) setelah menerima suatu gaya terus-menerus secara berulang-ulang. Pelopor dalam penelitian mengenai kelelahanlogam adalah Wohler (Jerman) dan Fairbain (inggris) tahun 1860. Pengamatan yang lebih mendetail terhadap kelelahan logam, dilakukansejak 1903 oleh Ewing dan Humparey yangmengarah pada lahirnya teori Mekanisme Patah lelah hingga saat ini.

Mekanisme patah lelah adalah terdiri atas 3 tahap kejadian yaitu:

1. Tahap awal terjadinya retakan (Crack Inisiation)

2. Tahap penjalaran retakan (Crack Propagation)

3. Tahap akhir kerusakan / patah (Final Fracture)

4.

Cara kerja uji fatik bending adalah untuk menentukan fatik suatu bahan, pengujian yang dilakukan dengan cara benda uji di jepit pada ragum penjepit yang dihubungkan dengan poros yang digerakan oleh motor listrik dan pada poros penjepit di beri pemberat, kemudian benda uji tersebut di putar, pada waktu tertentu benda uji tersebut mengalami kelelahan fatik sehingga akan patus (patah).Sebagaimana prilaku bahan terhadap pembebanan, semua bahan akan mengalami perubahan bentuk akibat pembebanan berulang.

Proses kerusakan fatik bending di mulai dari pembebanan berulang pada bahan yang akan di uji selama waktu tertentu sehingga terbentuk regangan plastic pada daerah konsentrasi tegangan. Regangan plastic ini akan memicu terbentuknya inisiasi retak dan selanjutnya akan tumbuh dan merambat dan sampai akhirnya terjadi kerusakan (patah).

\section{Mekanisme kegalan fatik bending}

Kegagalan fatik bendingdimulai dengan terjadinya regangan plalstik secara lokal. Bila slip terjadi, maka slip tersebut akan terlihat pada permukaan logam sebagai suatu tangga yang disebabkan oleh pergerakan logam sepanjang bidang slip. Demikian seterusnya maka lama kelamaan akan terjadi suatu retak.

Siklus untuk menimbulkan awal retak dan penjalaran retak tergantung pada tegangan 
yang bekerja. Bila tegangan yang bekerja tinggi maka waktu terbentuknya awal retak akan lebih pendek. Pada tegangan yang sangat rendah maka hampir seluruh umur lelah digunakan untuk membentuk awal retak. Pada tegangan yang tinggi sekali retak terbentuk sangat cepat.

Retak ini begitu kecil sehingga tidak bisa dilihat oleh mata . Sekali suatu retak muncul, pengaruh pemusatan tegangan menjadi tambah besar dan retak tersebut akan maju lebih cepat. Begitu ukuran luas yang menerima tegangan berkurang, tegangan bertambah besar sampai akhirnya luas yang tersisa tiba - tiba gagal menahan tegangan tersebut. Karena itu kegagalan lelah di tandai dari perkemabngan retak yang ada dan kepatahan mendadak yang mirip kepatahan bahan rapuh.

\section{Beban}

Beban siklik adalah pembebanan berulang, seperti tekanan berulang yang teratur dalam suatu bagian, yang kadang-kadang menyebabkan kelelahan. Istialah pembebanan siklik menyaratkan system pembebanan yang menunjukan tingkat keteraturan baik dalam besarnya dan frekuensinya. Sistem pembebanan yang cenderung siklik dalam arti ini memang ditemui dalam praktek. Karakter beban tersebut dapat bervariasi dari aplikasi satu ke aplikasi yang lain.

\section{Bending}

Pengujian bending merupakan salah satu pengujian sifat mekanik bahan yang dilakukan terhadap spesimen dari bahan baik bahan yang akan digunakan sebagai konstruksi atau komponen yang akan menerima pembebanan lengkung maupun proses pelengkungan dalam pembentukan. Dalam proses pengujian lengkung yang dilakukan terhadap material sebagai bahan teknik memilki tujuan pengujian yang berbeda tergantung kebutuhannya

\section{Putaran}

Pengertian siklus adalah putaran waktu yg di dalamnya terdapat rangkaian kejadian yang berulang-ulang secara tetap dan teraturatau gerakan melingkar yang sesuai dengan arah jarum jam atau sebaliknya untuk mengetahui jumlah putaran pada spesimen yang di uji. Putaran yang mempengaruhi fatik bending pada pengujian ini salah satunya beban dan jumlah siklus putaran, besar nilai putaran dapat di ukur dengan tachometer, dan putaran tersebut digunakan untuk mendapatkan pengaruh pembebanan pada spesimen.

\section{Benda Uji}

Benda uji yang digunakan pada umumnya mempunyai penampang lingkaran atau segi empat dengan ujung yang lebih tebal sebagai tempat penjepitan agar patahan yang terjadi berkurang pada bagian ini dan bagian yang terpengaruh oleh pembebenan bagian tengah diberi ukuran khusus. Setiap material yang diuji dibuat dalam bentuk sampel kecil atau spesimen. Spesimen pengujian dapat mewakili seluruh material apabila berasal dari jenis, komposisi dan perlakuan yang sama.

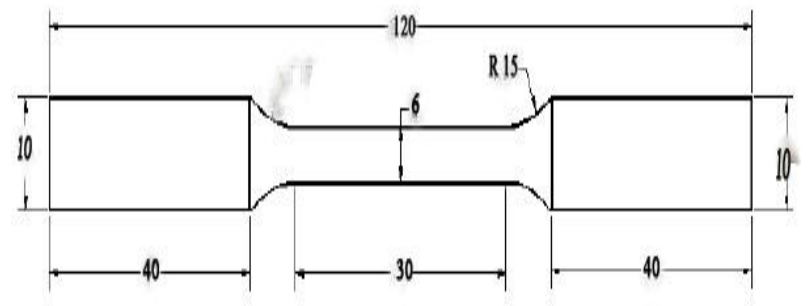

Gambar 1. Spesimen uji fatik bending

\section{Sifat mekanik}

Sifat mekanik didefinisikan sebagai ukuran kemampuan bahan untuk membawa atau menahan gaya atau tegangan. Pada saat menahan beban, atom-atom atau struktur molekul berada dalam kesetimbangan. Gaya ikatan pada struktur menahan setiap usaha untuk mengganggu kesetimbangan ini, misalnya gaya luar atau beban.

Berikut adalah beberapa sifat mekanik yang penting untuk diketahui :

1. Kekuatan, menyatakan kemampuan bahan untuk menerima tegangan tanpa menyebabkan bahan menjadi patah. Kekuatan ini ada beberapa macam, tergantung pada jenis beban yang bekerja atau mengenainya. Contoh 
kekuatan tarik, kekuatan geser, kekuatan tekan, kekuatan torsi, dan kekuatan lengkung.

2. Kekerasan, dapat didefenisikan sebagai kemampuan suatu bahan untuk tahan terhadap penggoresan, pengikisan (abrasi), identasi atau penetrasi. Sifat ini berkaitan dengan sifat tahan aus (wear resistance). Kekerasan juga mempunya korelasi dengan kekuatan.

3. Kekenyalan (elasticity), menyatakan kemampuan bahan untuk menerima tegangan tanpa mengakibatkan terjadinya perubahan bentuk yang permanen setelah tegangan dihilangkan. Bila suatu benda mengalami tegangan maka akan terjadi perubahan bentuk. Apabila tegangan yang bekerja besarnya tidak melewati batas tertentu maka perubahan bentuk yang terjadi hanya bersifat sementara, perubahan bentuk tersebut akan hilang bersama dengan hilangnya tegangan yang diberikan. Akan tetapi apabila tegangan yang bekerja telah melewati batas kemampuannya, maka sebagian dari perubahan bentuk tersebut akan tetap ada walaupun tegangan yang diberikan telah dihilangkan. Kekenyalan juga menyatakan seberapa banyak perubahan bentuk elastis yang dapat terjadi sebelum perubahan bentuk yang permanen mulai terjadi, atau dapat dikatakan dengan kata lain adalah kekenyalan menyatakan kemampuan bahan untuk kembali ke bentuk dan ukuran semula setelah menerima bebang yang menimbulkan deformasi.

4. Kekakuan (stiffness), menyatakan kemampuan bahan untuk menerima tegangan/beban tanpa mengakibatkan terjadinya perubahan bentuk (deformasi). Dalam beberapa hal kekakuan ini lebih penting daripada kekuatan.

5. Plastisitas (plasticity) menyatakan kemampuan bahan untuk mengalami sejumlah deformasi plastik (permanen) tanpa mengakibatkan terjadinya kerusakan. Sifat ini sangat diperlukan bagi bahan yang akan diproses dengan berbagai macam pembentukan seperti forging, rolling, extruding dan lain sebagainya. Sifat ini juga sering disebut sebagai keuletan (ductility). Bahan yang mampu mengalami deformasi plastik cukup besar dikatakan sebagai bahan yang memiliki keuletan tinggi, bahan yang ulet (ductile). Sebaliknya bahan yang tidak menunjukkan terjadinya deformasi plastik dikatakan sebagai bahan yang mempunyai keuletan rendah atau getas (brittle).

6. Ketangguhan (toughness), menyatakan kema mpuan bahan untuk menye- rap sejumlah energi tanpa mengakibatkan terjadinya kerusakan. Juga dapat dikatakan sebagai ukuran banyaknya energi yang diperlukan untuk mematahkan suatu benda kerja, pada suatu kondisi tertentu. Sifat ini dipengaruhi oleh banyak faktor, sehingga sifat ini sulit diukur.

7. Kelelahan (fatigue), merupakan kecendrungan dari logam untuk patah bila menerima tegangan berulang - ulang (cyclic stress) yang besarnya masih jauh dibawah batas kekuatan elastiknya. Sebagian besar dari kerusakan yang terjadi pada komponen mesin disebabkan oleh kelelahan ini. Karenanya kelelahan merupakan sifat yang sangat penting, tetapi sifat ini juga sulit diukur karena sangat banyak faktor yang mempengaruhinya.

8. Creep, atau bahasa lainnya merambat atau merangkak, merupakan kecenderungan suatu logam untuk mengalami deformasi plastik yang besarnya berubah sesuai dengan fungsi waktu, pada saat bahan atau komponen tersebut tadi menerima beban yang besarnya relatif tetap.

\section{Bentuk patahan}

Setiap material pasti mempunyai umur lelah yang berbeda - beda tergantung dari material itu sendiri. Setelah material melewati masa umur lelahnya maka material tersebut akan mengalami keklelahan. Akibatnya material yang bersangkutan akan mengalami patah. Patah yang dialami oleh material dibedakan menjadi 2 jenis, yaitu patah ulet dan patah getas.

\section{Uji fatik bending}

Fungsi uji fatik bending adalah menguji kekuatan patah berdasarkan beban bending yang berbeda-beda mulai dari beban rendah sampai beban yang besar. 
Cara kerja uji fatik bending yaitu benda uji di jepit pada cekam penjepit yang dihubungkan dengan poros yang digerakan oleh motor listrik dan pada poros penjepit di beri beban, kemudian benda uji tersebut di putar. Pada waktu tertentu benda uji tersebut mengalami kelelahan fatik bendingsehingga akan patus (patah) Proses kerusakan fatik bending di mulai daripembebananberulang pada bahan yang akan diuji selama waktu tertentu sehingga terbentuk renggangan platik pada daerah konsentrasi tegangan. Regangan plastik ini akan memicu terbentuknya inisiasi.

\section{Prinsip Kerja Uji fatik bending}

Benda uji di jepit pada cekam penjepit yang dihubungkan dengan poros yang digerakan oleh motor listrik dan pada poros penjepit di beri beban, kemudian benda uji tersebut di putar. Pada waktu tertentu benda uji tersebut mengalami kelelahan fatik sehingga akan putus (patah).

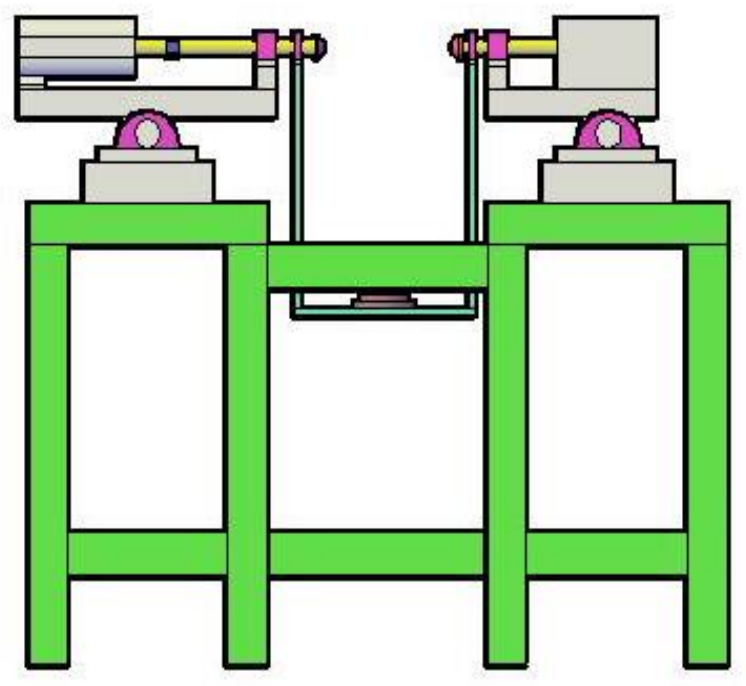

Gambar 2. Alat uji Fatik Bending

\section{METODE PENELITIAN}

Dalam penelitian ini metode yang digunakan adalah eksperimen. Metode eksperimen yaitu tata cara atau proses pengujian yang bertujuan untuk memudahkan dalam penelitian

\section{Proses Pengujian fatik Bending}

Cara kerja mesin uji fatik bending adalah untuk menentukan fatigue suatu bahan, pengujian yang dilakukan dengan cara benda uji di jepit pada ragum penjepit yang dihubungkan dengan poros yang digerakan oleh motor listrik dan pada poros penjepit di beri pemberat, kemudian benda uji tersebut di putar. Pada waktu tertentu benda uji tersebut mengalami kelelahan fatik bending sehingga akan patus (patah)

\section{Langkah Pengujian fatik Bending}

Pengujian ini diawali dengan melakukan uji kekerasan untuk mengetahui nilai kekerasan bahan dari spesimen yang hendak di uji. Setelah nilai kekerasan bahan dikekatahui, kemudian melakukan pengujian uji fatik bending, hingga didapatkan kondisi dimana benda uji mengalami putus.

1. Memasang spesimen pada mesin uji fatik bending

2. Memasang beban $9,81 \mathrm{~N}$

3. Melakukan pengecekan supaya kencang pada cekam spesimen dan beban sehingganya pada saat pengujian tidak terlepas dari dudukan

4. Menghidupkan mesin bersamaan dengan menghidupkan penghitung waktu untuk memulai pengujian.

5. Mengecek putaran motor dengan tachometer

6. Saat spesimen patah seketika pula mematikan motor dan menghentikan penghitung waktu.

7. Mencatat waktu yang diperoleh

8. Menandai material untuk pengujian pertama.

9. Mengulangi langkah 2-7 untuk pengujian menggunakan beban selanjutnya. Yaitu, 14,72 $\mathrm{N}, 19,62 \mathrm{~N}, 24,53 \mathrm{~N}$, dan 29,43 N

10. Mencatat seluruh data dan kejadian selama pengambilan data.

\section{HASIL DAN PEMBAHASAN}

\section{Data Hasil Untuk Spesimen 1}

Pada grafik gambar 3 untuk diameter 4 $\mathrm{mm}$ menunjukan bahwasanya semakin berat beban maka waktu putus spesimen akan lebih cepat tidak terkecuali pada diameter $5 \mathrm{~mm}$ dan $6 \mathrm{~mm}$. 


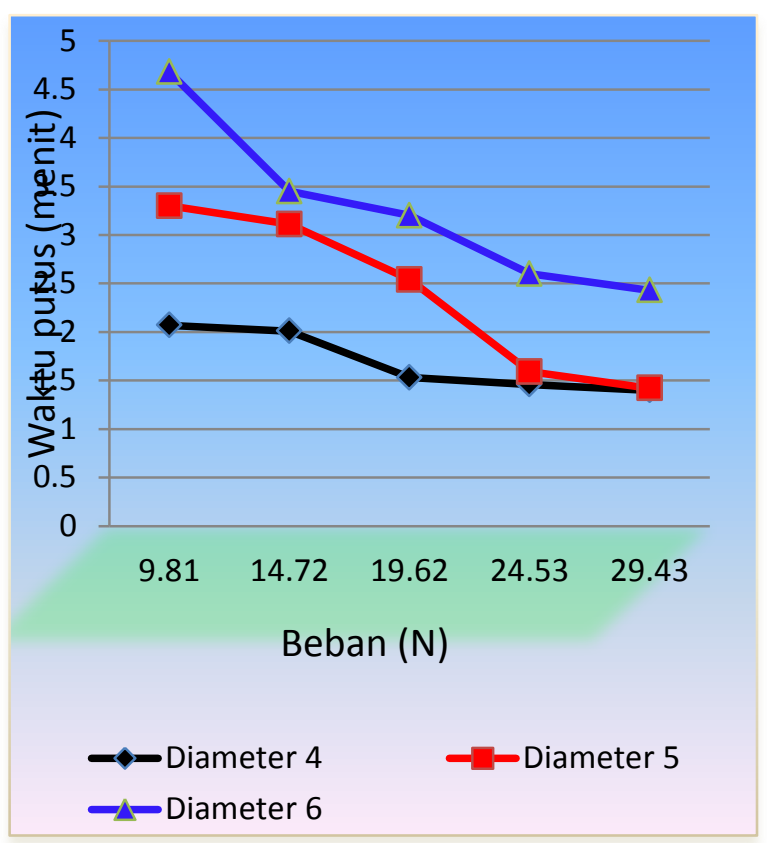

Gambar 3. (Grafik Waktu Putus - Beban pada spesimen 1)

Hal ini di sebabkan beban yang bekerja pada spesimen lebih besar sehingga mengakibatkan waktu putus spesimen lebih cepat, Untuk diameter $5 \mathrm{~mm}$ dan $6 \mathrm{~mm}$ terlihat tidak terlalu jauh selisih waktu putusnya pada beban $24,53 \mathrm{~N}$ dan 29,43 N.

\section{Data Hasil Untuk Spesimen 2}

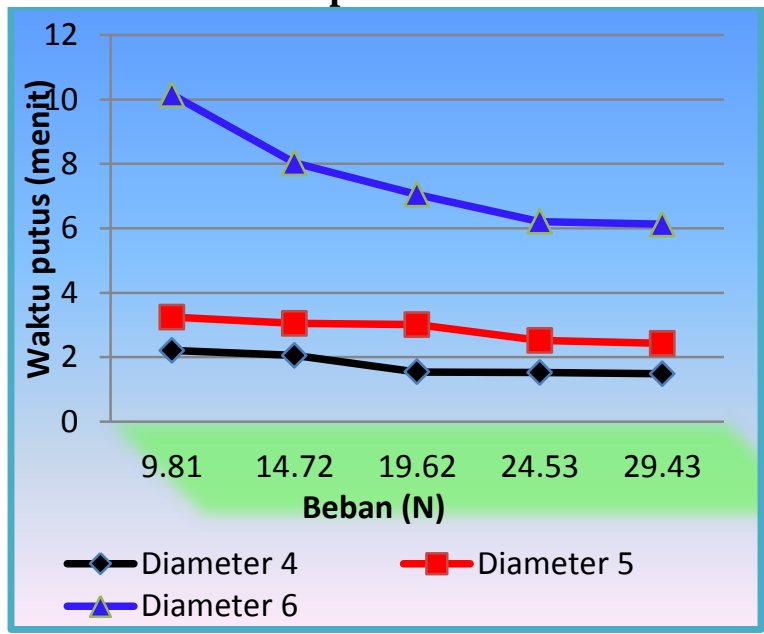

Gambar 4. (Grafik Waktu Putus - Beban pada Spesimen 2 )

Pada grafik ini untuk diameter $4 \mathrm{~mm}$ menunjukan bahwasanya semakin berat beban maka waktu putus spesimen akan lebih cepat tidak terkecuali pada diameter $5 \mathrm{~mm}$ dan $6 \mathrm{~mm}$. Hal ini di sebabkan beban yang bekerja pada spesimen lebih besar sehingga mengakibatkan waktu putus spesimen lebih cepat, untuk diameter $6 \mathrm{~mm}$ terlihat selisih waktu putusnya sangat jauh di bandingkan diameter $4 \mathrm{~mm}$ dan $5 \mathrm{~mm}$.pada grafik ini menunjukan sifat patah ulet pada bahan lebih terlihat jelas pada pengujian dengan diameter $6 \mathrm{~mm}$ di bandingkan diameter di bawahnya.

\section{Data Uji Kekerasan Pada Spesimen}

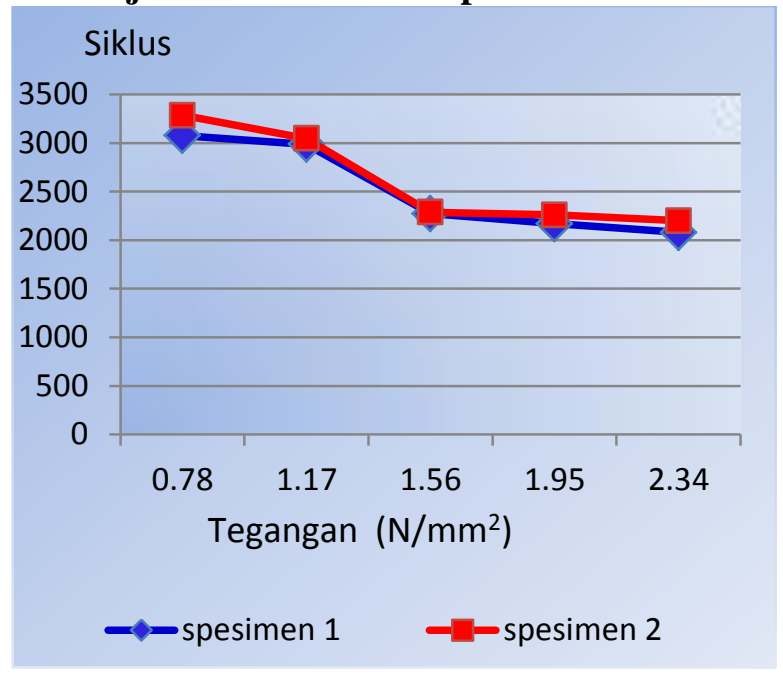

Gambar 5. (Grafik siklus - tegangan pada diameter 4 )

Dari hasil pengujian menunjukan bahwa siklus putaran sangat erat hubungan nya dengan tegangan benda uji , karena semakin besar tegangan maka akan semaikin kecil jumlah siklus putaranya ,dan sebaliknya.

Pada grafik siklus tegangan ini menunjukan bahwasanya perbandingan antara spesimen 2 sedikit lebih besar jumlah siklusnya dari pada spesimen yang ke 1 , dengan perbedaan yang tidak terlalu jauh diantara kedua spesimen tersebut untuk diameter yang sama.

Dari hasil pengujian dalam pengamatan seperti gambar 6 menunjukan bahwa siklus putaran sangat erat hubungannya dengan tegangan benda uji, karena semakin besar tegangan maka akan semaikin kecil jumlah siklus putaranya , dan sebaliknya. 


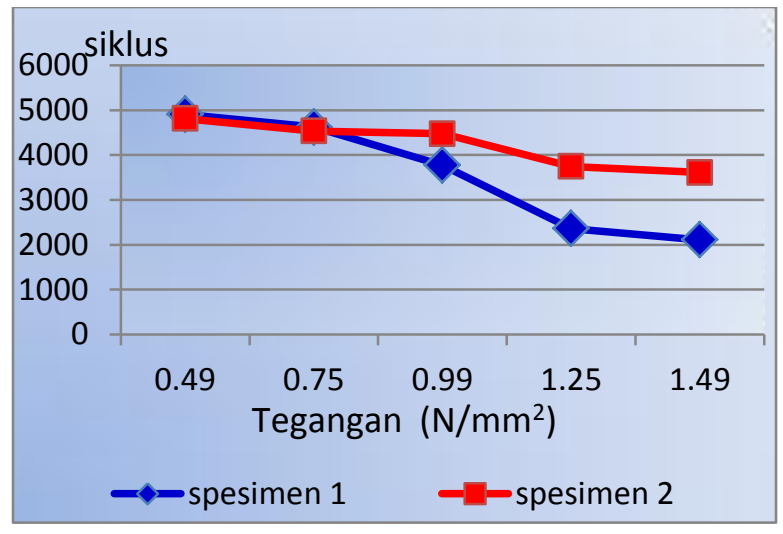

Gambar 6. (Grafik siklus - tegangan pada diameter 5)

Di dalam grafik ini menunjukan bahwasanya perbandingan spesimen 1 lebih kecil jumlah siklusnya dari pada spesimen yang 2 , dengan perbedaan yang tidak terlalu jauh diantara kedua spesimen tersebut untuk diameter yang sama. Hanya pada tegangan 0,99 sampai 1,49 menunjukan perbedaan yang sangat jelas

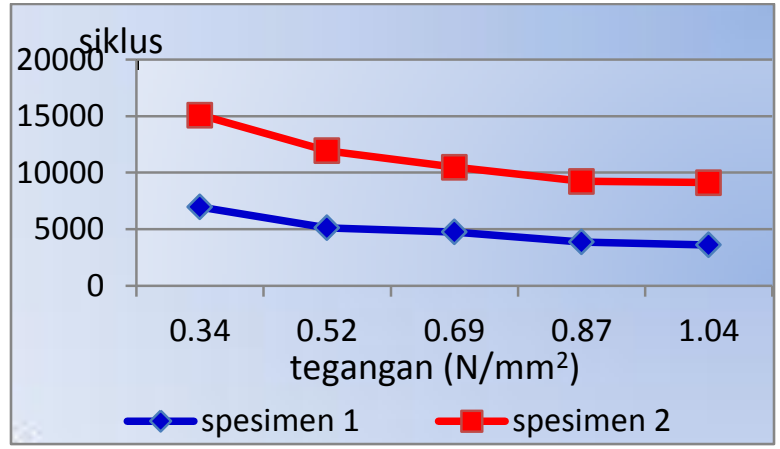

Gambar 7. (Grafik siklus - tegangan pada diameter 6)

Dari hasil pengujian menunjukan bahwa siklus putaran sangat erat hubungan nya dengan tegangan benda uji , karna semakin besar tegangan maka akan semaikin kecil jumlah siklus putaranya ,dan sebaliknya.

Pada gambar 7. memperlihatkan bahwa perbandingan spesimen 2 lebih besar jumlah siklusnya dari pada spesimen yang 1, dengan perbedaan siklus yang terlihat sangat jauh diantara kedua spesimen tersebut untuk diameter yang sama hal ini terlihat jelas bahwa pada spesimen 1 menunjukan jenis patah getas nya dan untuk spesimen 2 menunjukan patah uletnya.

\section{PEMBAHASAN}

1) Di salam proses pengujian uji fatik bending ini Hubungan jumlah putaran dan beban terhadap kekuatan bahan uji ini menunjukan semakin kecil beban pada uji fatik bending maka jumlah siklus putaran akan semakin besar. dengan jumlah siklus tertinggi terdapat pada spesimen 1 yakni 6954,48 dengan beban 9,81 $\mathrm{N}$ dan siklus terendah yaitu 2080,4 pada beban 29,43 N dengan kekuatan bahan St 40 . Dan pada spesimen ke 2 menunjukan jumlah siklus tertinggi dengan jumlah 15085,9 pada beban 9,81 $\mathrm{N}$ untuk siklus terendah 2199,28 untuk beban 29,43 N pada kekuatan bahan $\mathrm{St}$ 37.

2) Pada pengujian ini putaran sangat berhubungan dengan tegangan benda uji karna semakin besar tegangan maka akan semaikin kecil jumlah siklus putaranya ,dan sebaliknya. Pada nilai hubungan tegangan dengan siklus putaran terlihat pada spesimen spesimen 1 tegangan terkeil $0,34 \mathrm{~N} / \mathrm{mm}^{2}$ dengan hasil jumlah siklus 694,48 dan tegangan terbesar 2,34 N/mm² pada jumlah siklus 2080,4 . Dan untuk spesimen 2 dengan hasil tegangan terkecil $0,34 \mathrm{~N} / \mathrm{mm}^{2}$ untuk jumlah siklus tertinggi 15085,9.

3) Pada spesimen 1 menunjukan nilai kekerasan yang berbeda dengan spesimen 2, yaitu spesimen uji 1 menunjukan nilai kekerasan (HRC) 40,98 dan spesimen ke2 (HRC) 39,90. Di dalam proses pengujian terlihat hasil bahwa nilai kekerasan yang tinggi menunjukan patah getas pada bahan nya dan nilai kekerasan yang rendah yang meniliki bahan patah ulet.

\section{KESIMPULAN}

Setelah melakukan pengujian diketahui hubungan siklus putaran dan beban terhadap kekuatan bahan pada uji fatik bending. data hasil pengujiaan maka dapat ditarik kesimpulan bahwasanya:

1) Jumlah siklus putaran tertinggi 15085,9 dengan beban 9,81 $\mathrm{N}$ dan Jumlah siklus putaran terendah 2199,28 dengan beban 2,34 $\mathrm{N}$ pada kekuatan bahan St 37. Untuk Jumlah 
siklus putaran tertinggi 6954,48 dengan beban 9,81 N. jumlah siklus putaran terendah 2080,4 dengan beban 29,43 N pada kekuatan bahan St 40

2) Pada spesimen 1 menunjukan hasil Tegangan tertinggi $2,34 \mathrm{~N} / \mathrm{mm}^{2}$, jumlah siklus 2080,4 dan Tegangan terendah $0,34 \mathrm{~N} / \mathrm{mm}^{2}$ dengan jumlah siklus 6954,48. Untuk hasil pada spesimen ke 2 menunjukan Tegangan tertinggi 2,34 N/mm ${ }^{2}$ jumlah siklus 2199,28 dan Tegangan terendah $0,34 \mathrm{~N} / \mathrm{mm}^{2}$ dengan jumlah siklus 15085,9

3) Pada bahan uji menggunakan Baja St 37 dengan nilai kekerasan (HRC) 40,98 yang lebih memiliki jenis patah getas di bandingkan baja St 40 dengan nilai kekerasan (HRC) 39,90 , yang lebih memiliki patah ulet

\section{DARTAR PUSTAKA}

1. Bondan T.Sofyan. 2010.'Pengantar Material Teknik",Jakarta.Salemba Teknika.

2. Fathy. Life Impact Test(online) http://ahmadfa thy03.wordpress.com/2012/04/23/life-impacttest/ di akses 7 April 2013.

3. Herman jutz,eduard scharkus. 1996. "Westerman Tables for the Metal trade",India.

4. Jac.Stolk,C.Kros. 1981. "Elemen Konstruksi dan Bangunan Mesin", Jakarta. Erlangga.

5. Muhnabil, Analisa Tingkat Karat Pada Plat Baja ST 37 Dalam Lingkungan Air laut dan Asin.

6. Sularso.1983. "Dasar perencanaan dan pemilihan elemen mesin", Jakarta. pradnya paramita. 